\title{
First Case of Brucella Pneumonia in a Lung Transplant Patient: Case Report and Review of the Literature
}

\author{
Abdulaziz H. Abed ${ }^{1}$, Reem S. Almaghrabi ${ }^{2}$, Imran Nizami ${ }^{3}$ \\ 1. Medicine and Surgery, Alfaisal University College of Medicine, Riyadh, SAU 2. Infectious Diseases, King Faisal \\ Specialist Hospital and Research Centre, Riyadh, SAU 3. Organ Transplant, King Faisal Specialist Hospital and \\ Research Centre, Riyadh, SAU
}

Corresponding author: Reem S. Almaghrabi, dr_reem2002@yahoo.com

\begin{abstract}
Brucella is one of the most common zoonotic diseases worldwide. It is endemic in the Mediterranean basin. Brucella pneumonia is a rare complication of brucellosis that can present with a variety of clinical and radiological manifestations. It was described only once previously in the setting of solid organ transplant.

A 32-year-old female from Saudi Arabia with cystic fibrosis and bronchiectasis presented five weeks after a bilateral lung transplant with fever and cough. Investigation showed high inflammatory markers in addition to a pulmonary infiltrate in the chest imaging. All microbiological workups were negative including bronchoalveolar lavage cultures. Brucella serology was positive and she was started on anti-Brucella therapy which resulted in complete resolution of her symptoms and radiological changes. This case demonstrates an unusual presentation of Brucellosis. It highlights the importance of epidemiology in evaluating posttransplant infections. We reviewed and summarized the literature on brucellosis post solid organ transplant and the various treatment regimens for Brucella pneumonia.
\end{abstract}

This is the first case report of Brucella pneumonia in a lung transplant patient. Brucella is a rare complication post solid organ transplant but it has a good prognosis.

Received 05/29/2020 Review began 06/10/2020 Review ended 06/10/2020 Published 06/21/2020

(c) Copyright 2020 Abed et al. This is an open access article distributed under the terms of the Creative Commons Attribution License CC-BY 4.0., which permits unrestricted use, distribution, and reproduction in any medium, provided the original author and source are credited.
Categories: Infectious Disease, Transplantation

Keywords: lung transplantation, solid organ transplant, brucella, brucellosis, pneumonia, pulmonary infiltrate, serology

\section{Introduction}

Brucellosis is one of the most widespread zoonotic diseases in the world and is caused by infection with Brucella species, which are intracellular gram-negative coccobacilli [1]. Brucellosis is an endemic disease in several countries, such as those in the Arabian Peninsula. Saudi Arabia has an infection rate of about 70 per 100,000 people [2]. It is a multi-system disease and symptoms include fatigue, malaise, anorexia, and body aches. Fever is the most common sign [3].

Respiratory system involvement in brucellosis is rare, and the non-specific findings make the diagnosis difficult [4]. Brucellosis in the respiratory system results from inhalation of infected aerosol or through hematogenous spread and it can cause a variety of pulmonary manifestations including pleural effusions, pneumonia, lymphadenopathy, and pulmonary nodules, and it can be found in up to $16 \%$ of complicated cases [1]. Brucella infection has been reported in organ transplant recipients and is acquired either as donor-derived infection, blood transfusion-related, or due to a new infection post-transplantation [4]. Here, we report the first case of Brucella pneumonia in a lung transplant patient and review the literature on Brucella pneumonia.

\section{Case Presentation}

A 32-year-old female patient known to have cystic fibrosis and bronchiectasis with respiratory failure underwent a double lung transplant at the end of November 2017 under methylprednisolone induction. Her pre-transplant workup is summarized in Table 1. 


\section{Cureus}

\begin{tabular}{|l|l|}
\hline Test & Results \\
\hline CMV IgG & D+/R+ \\
EBV & D+/R+ \\
QuantiFERON TB & Negative \\
HAV & Immune \\
HBV & Immune \\
HCV antibody & Negative \\
Microbiology & Fully susceptible Pseudomonas aeruginosa Achromobacter xylosoxidans susceptible to TMP-SMX \\
\hline
\end{tabular}

\section{TABLE 1: Pre-transplant infectious diseases workup}

CMV: Cytomegalovirus; EBV: Epstein-Barr virus; TB: Tuberculosis; HAV: Hepatitis A virus; HBV: Hepatitis B virus; HCV: Hepatitis C virus; D: Donor; R: Recipient; TMP-SMX: Trimethoprim-sulfamethoxazole.

The patient had an uneventful course post-transplant and was discharged two weeks later from the hospital on tacrolimus $7 \mathrm{mg}$ twice daily, mycophenolate mofetil $1 \mathrm{~g}$ twice daily, and prednisone $20 \mathrm{mg}$ daily for immunosuppressant medication, and trimethoprim-sulfamethoxazole $(800 \mathrm{mg} / 160 \mathrm{mg})$ tablets three times per week (TMP-SMX), valganciclovir $450 \mathrm{mg}$ daily, isoniazid $300 \mathrm{mg}$ daily, inhaled amphotericin B and itraconazole for antimicrobial prophylaxis, in addition to pancreatic enzymes.

Five weeks after the transplantation, the patient presented to the clinic for a follow-up visit, during which she reported subjective fever, dry cough, and four kilograms of weight loss since her hospital discharge. Her symptoms were associated with central pleuritic chest pain. She reported shortness of breath during the same period that worsened when lying down, and that improved partially when seated. She reported two brief episodes of chills, with no rigors or night sweat. The patient did not experience headache, neck pain, skin rash, photophobia, abdominal pain, change in bowel habit, dysuria, changed urine color, sputum, use of antibiotics, travel, or contact with tuberculosis patients or animals.

On physical examination, the patient was conscious, alert, and oriented. Her temperature on admission was $37.9^{\circ} \mathrm{C}$, heart rate was 89 per minute, blood pressure was $105 / 62 \mathrm{mmHg}$, respiratory rate $24 / \mathrm{min}$ and oxygen saturation was $96 \%$ on a 1-liter nasal cannula. Chest: Not in respiratory distress with vesicular breath sounded bilateral, with decreased breath sounds over the bases with dullness on percussion. Cardiovascular: Normal first and second heart sounds with no added sounds. Abdomen: Soft, lax, non-tender with no organ enlargement, no lower limb edema.

The patient was admitted to the hospital for further examination. Her laboratory investigations on admission are summarized in Table 2. 


\section{Cureus}

\begin{tabular}{|c|c|c|}
\hline & Result & Reference Range \\
\hline WBC & 13.54 & $3.9-11 \times 10^{9} / \mathrm{L}$ \\
\hline $\mathrm{Hb}$ & 98 & $11-160 \mathrm{~g} / \mathrm{L}$ \\
\hline НCT & 0.284 & $0.32-0.47 \mathrm{~L} / \mathrm{L}$ \\
\hline Platelets & 422 & $155-435 \times 10^{9} / \mathrm{L}$ \\
\hline PT & 14.7 & 12.3-14.2 seconds \\
\hline PTT & 36.1 & $30.5-40.4$ seconds \\
\hline INR & 1.1 & $0.9-1.1$ \\
\hline Potassium & 5.2 & 3.3-5 mmol/L \\
\hline Sodium & 136 & 135-147 mmol/L \\
\hline CRP & 153 & $<3$ mg/L \\
\hline ESR & 132 & $0-15 \mathrm{~mm} / \mathrm{Hr}$ \\
\hline Urea & 6.1 & $4.2-7.2 \mathrm{mmol} / \mathrm{L}$ \\
\hline Creatinine & 65 & 64-115 umol/L \\
\hline ALT & 22.9 & $10-45 \mathrm{U} / \mathrm{L}$ \\
\hline AST & 20.1 & $10-45 \mathrm{U} / \mathrm{L}$ \\
\hline Alkaline phosphatase & 80.9 & 46-122 U/L \\
\hline Tacrolimus level & 13.2 & 3-15 ug/L \\
\hline
\end{tabular}

\section{TABLE 2: Laboratory investigations on second admission}

ALT: Alanine aminotransferase; AST: Aspartate aminotransferase; CRP: C-reactive protein; ESR: Erythrocyte sedimentation rate; Hb: Hemoglobin; HCT: Hematocrit; INR: International normalized ratio; PT: Prothrombin time; PTT: Partial thromboplastin time; WBC: White blood cells.

It showed leukocytosis, mildly elevated platelets, and elevated inflammatory markers. Chest X-ray (Figure 1) and CT scan (Figure 2) of the chest showed bilateral pulmonary infiltrate and peri-hilar opacities. The patient was started on ceftazidime and TMP-SMX based on her prior microbiology results. Blood and sputum cultures were performed and were negative. 


\section{Cureus}

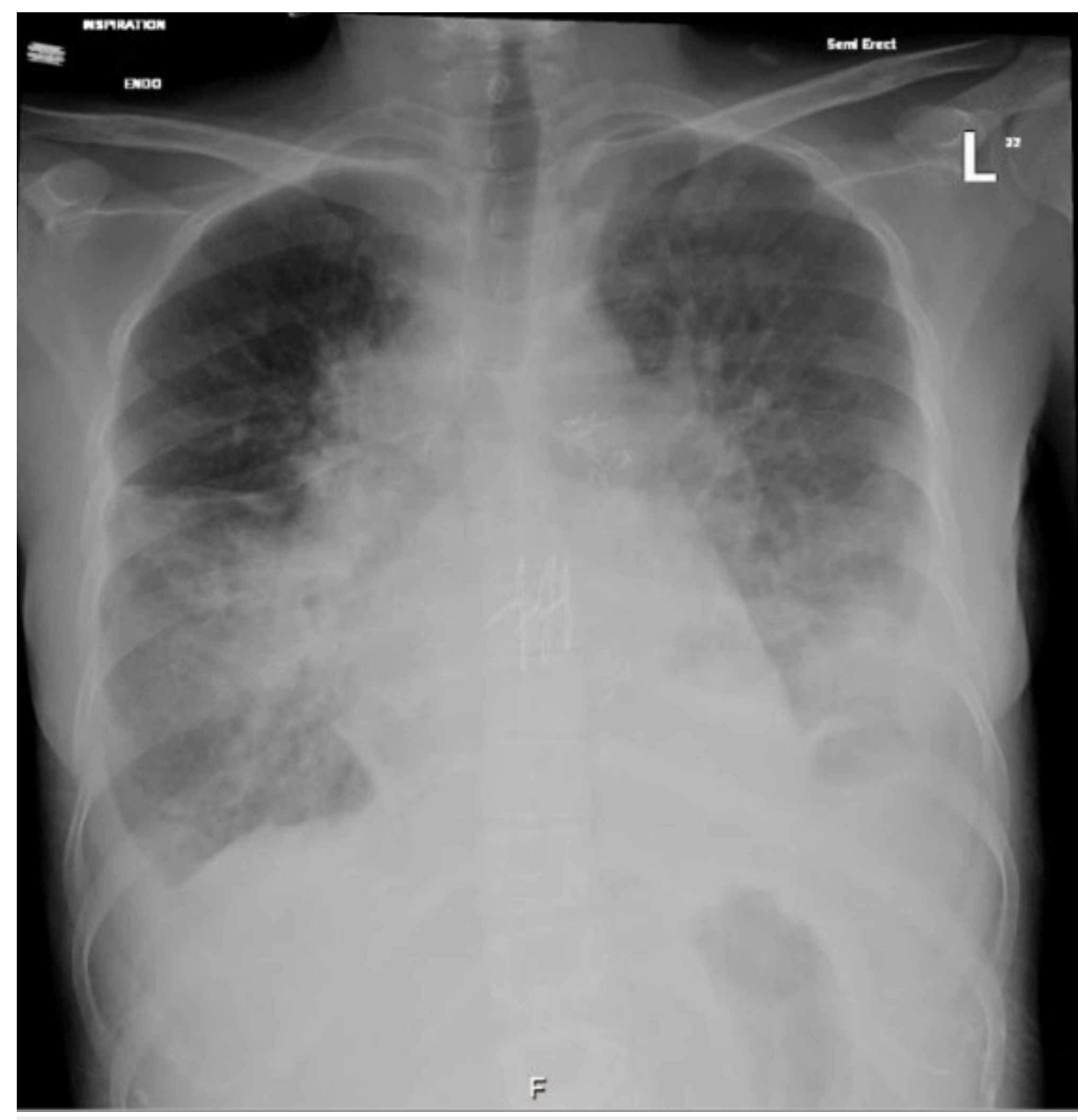

FIGURE 1: Patient's initial chest X-ray shows bilateral lower air space and perihilar opacity, bilateral pleural effusion.

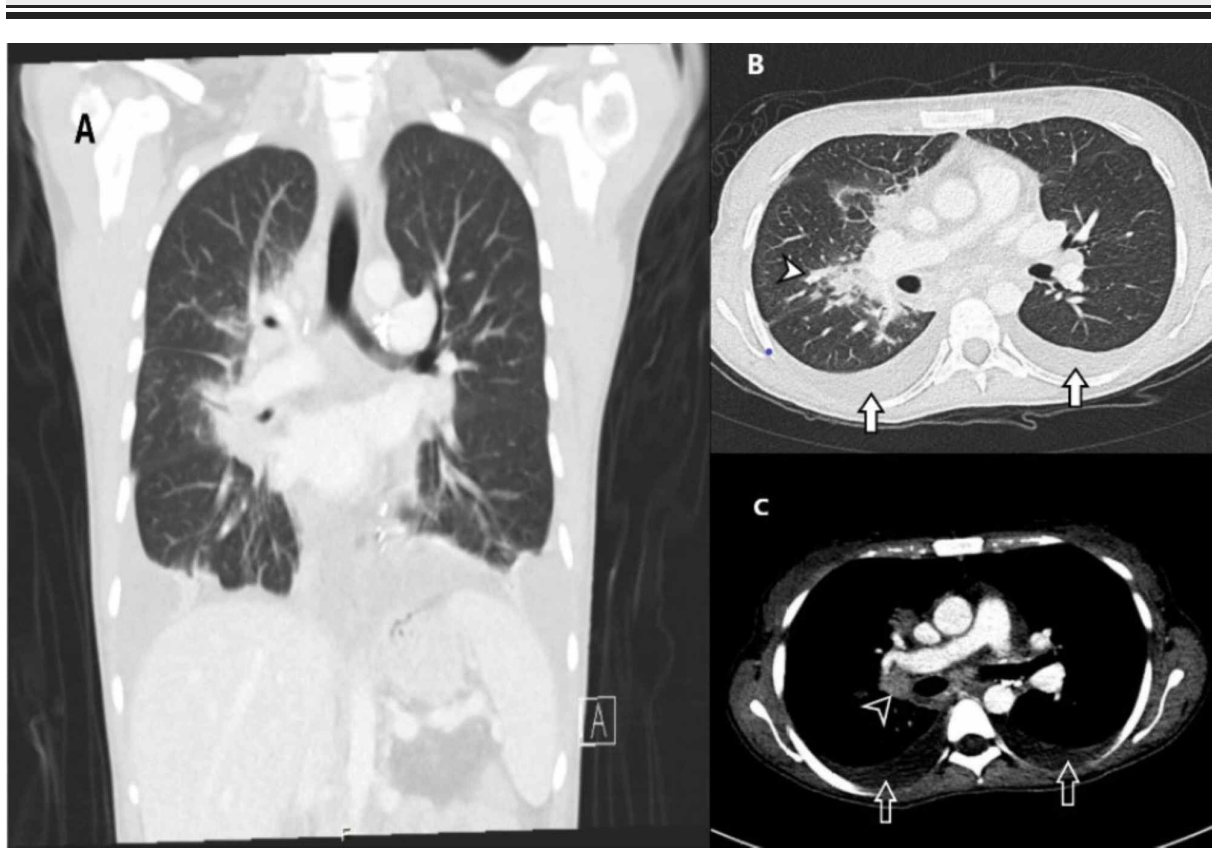

FIGURE 2: (A) Coronal CT image showing bilateral lower air space and perihilar opacity. (B) Bilateral pleural effusion (Arrows) and right perihilar opacity (Arrowhead). (C) Enlarged enhancing right hilar lymph 


\section{Cureus}

node (Arrowhead) and bilateral pleural effusion (Arrows).

Given the presence of a pulmonary infiltrate and mediastinal lymphadenopathy, additional analyses were done that included cytomegalovirus (CMV), Epstein-Barr virus (EBV) viral load, and serum cryptococcal antigen which all came back negative. Three sputum samples for acid-fast bacilli (AFB) stains, mycobacterial cultures, and Mycobacterium tuberculosis polymerase chain reaction (PCR) (GeneXpert MTB/RIF, Cephid, Sunnyvale, California, USA) came back negative. She underwent bronchoscopy for lavage and endobronchial ultrasound biopsies from mediastinal lymphadenopathy twice during admission, and results were negative for malignancy and granulomas, in addition to negative cultures, AFB stains, mycobacterial cultures, and Mycobacterium tuberculosis PCR. The patient continued to have spikes of fever as shown in Figure 3.

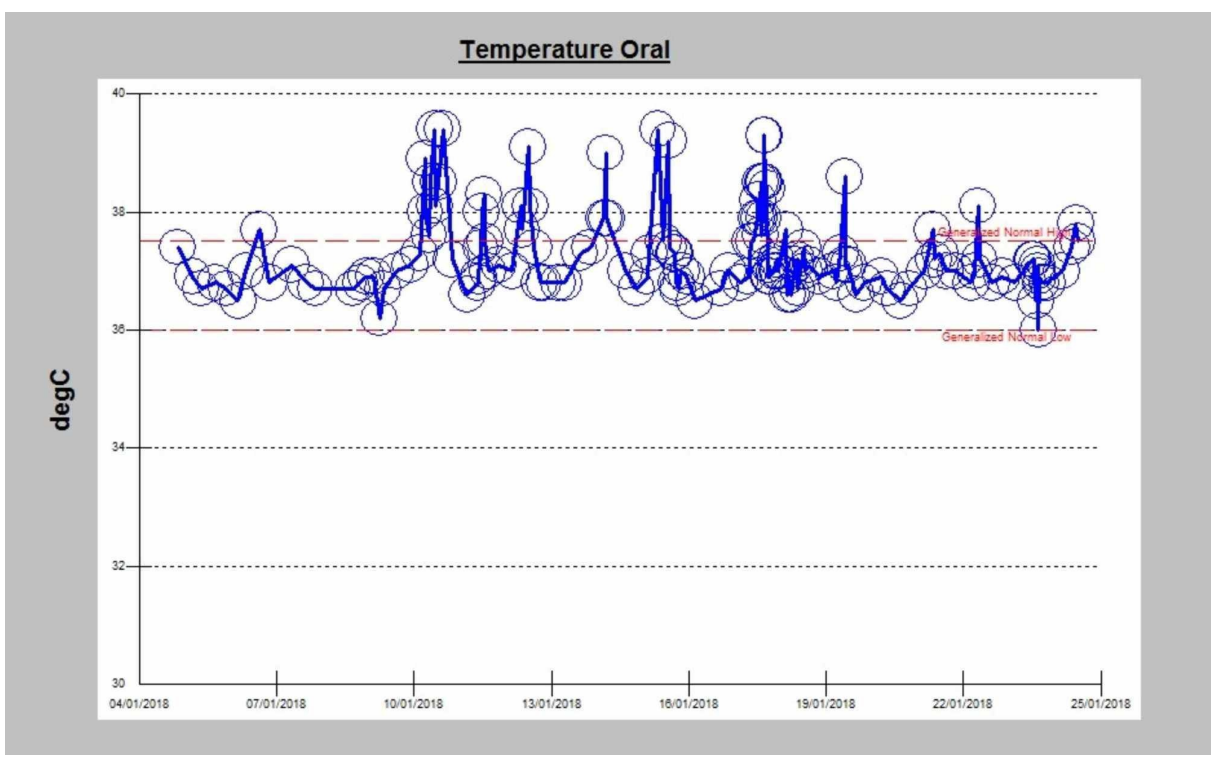

FIGURE 3: Temperature chart during patient admission and after starting treatment.

As part of the workup for persistent fever, Brucella serology was performed and this came back positive with IgG $<1: 20$ and total antibody 1:1280. The patient was not tested for Brucella prior to transplant, while donor serology and other recipient serology were negative. The patient denied any history of recent animal contact or consumption of raw dairy products but reported remote raw milk ingestion prior to the transplantation which raised the suspicion for an infection that was acquired prior to transplant, and that started to show clinical signs and symptoms after transplantation. The patient was started on streptomycin $1 \mathrm{~g}$ daily for two weeks and doxycycline $100 \mathrm{mg}$ twice daily for three months. Her repeat chest X-ray was performed six weeks after start of treatment. The previously observed infiltrates and opacities had disappeared (Figure 4). 


\section{Cureus}

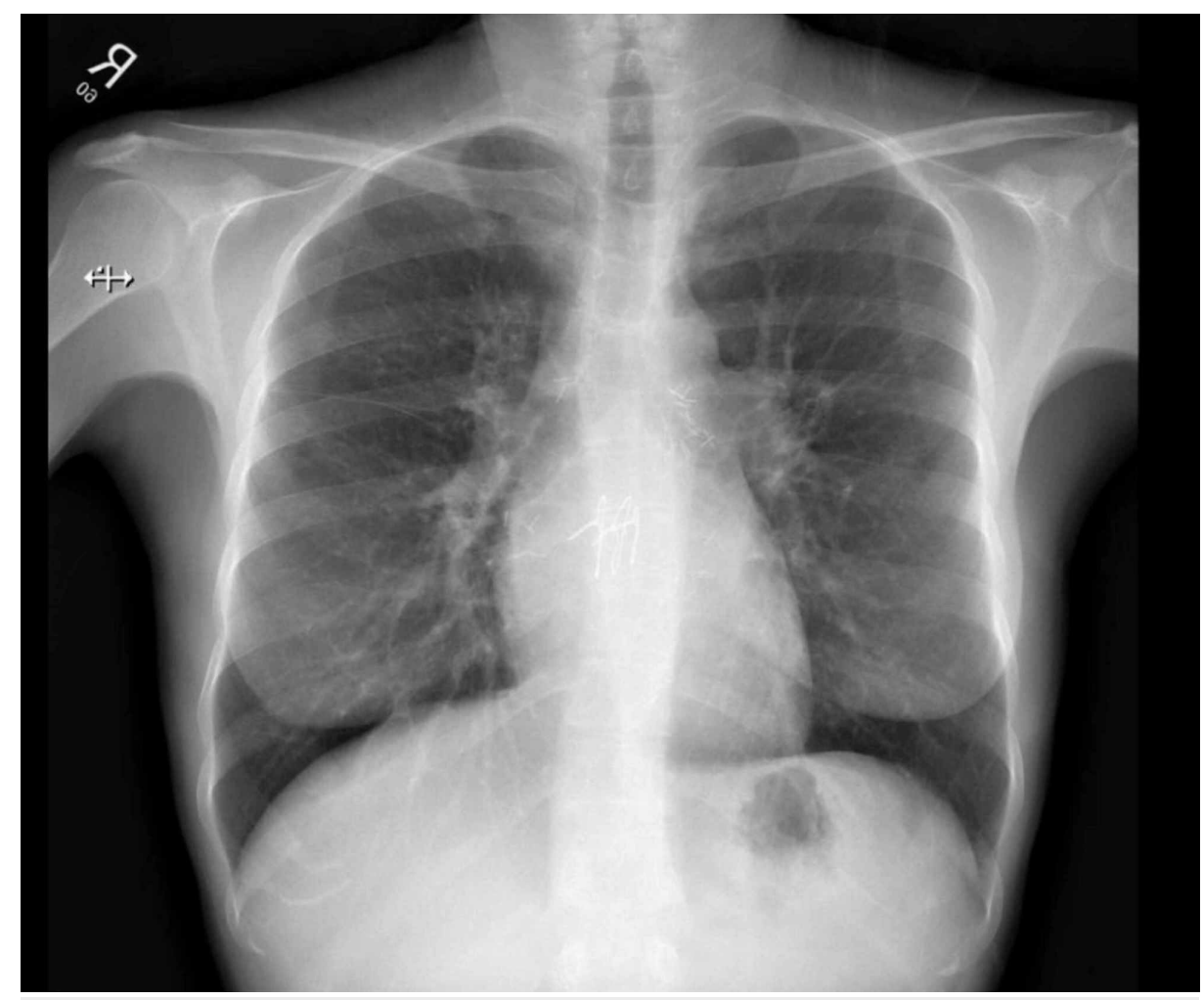

FIGURE 4: Chest X-ray six weeks after therapy.

\section{Discussion}

This is the first reported case of Brucella pneumonia in a patient post lung transplantation. The patient presented with classical symptoms of Brucella that included high-grade fever and weight loss [5]. A donorderived infection was ruled out with negative Brucella serology and blood culture from the donor at the time of the organ procurement. Human to human transmission of brucellosis has been reported to occur via blood transfusion, hematopoietic stem cell transplantation, and vertical transmission [6]. There are no reported cases of donor-derived Brucellosis after solid organ transplantation, which may be due to underreporting.

There are a few reported cases of Brucella infection post solid organ transplantation, mostly in renal transplant patients [7-10], liver transplant patients [11-13], and in one cardiac transplant patient [14]. These cases are summarized in Table 3. 


\section{Cureus}

\begin{tabular}{|c|c|c|c|c|c|c|c|c|}
\hline $\begin{array}{l}\text { Age in } \\
\text { years }\end{array}$ & $\begin{array}{l}\text { Organ } \\
\text { transplanted }\end{array}$ & $\begin{array}{l}\text { Time post- } \\
\text { transplant }\end{array}$ & Risk factors & Presentation & $\begin{array}{l}\text { Diagnosis of } \\
\text { Brucella }\end{array}$ & Treatment & $\begin{array}{l}\text { Duration } \\
\text { of therapy }\end{array}$ & Reference \\
\hline 41 & Kidney & 3 years & Not reported & $\begin{array}{l}\text { Fever and } \\
\text { weakness }\end{array}$ & Blood culture & $\begin{array}{l}\text { Doxycycline, TMP- } \\
\text { SMX, rifampin }\end{array}$ & 6 weeks & $\begin{array}{l}\text { Bishara et } \\
\text { al. [15] }\end{array}$ \\
\hline 56 & Kidney & 3 years & $\begin{array}{l}\text { Remote history of raw dairy } \\
\text { product consumption }\end{array}$ & $\begin{array}{l}\text { Fever and } \\
\text { confusion }\end{array}$ & Serology & Doxycycline, rifampin & 6 weeks & $\begin{array}{l}\text { Yousif and } \\
\text { Nelson [7] }\end{array}$ \\
\hline 58 & Kidney & 3 years & Raw cheese consumption & $\begin{array}{l}\text { Fever and } \\
\text { arthritis }\end{array}$ & $\begin{array}{l}\text { Blood/synovial } \\
\text { fluid culture }\end{array}$ & $\begin{array}{l}\text { Doxycycline, rifampin, } \\
\text { ciprofloxacin }\end{array}$ & $\begin{array}{l}\text { Not } \\
\text { reported }\end{array}$ & $\begin{array}{l}\text { Einollahi et } \\
\text { al. [8] }\end{array}$ \\
\hline 15 & Liver & 2 months & Lives in endemic area & $\begin{array}{l}\text { Fever and poor } \\
\text { appetite }\end{array}$ & Serology & Doxycycline, rifampin & 8 weeks & $\begin{array}{l}\text { Polat et al. } \\
\text { [13] }\end{array}$ \\
\hline 58 & Kidney & 3 years & Traveled to endemic country & $\begin{array}{l}\text { Fever, chills, } \\
\text { and sweating }\end{array}$ & Blood culture & $\begin{array}{l}\text { Tigecycline IV, } \\
\text { Minocycline, TMP- } \\
\text { SMX }\end{array}$ & $\begin{array}{l}2 \text { weeks } 3 \\
\text { months }\end{array}$ & $\begin{array}{l}\text { Ting et al. } \\
\text { [9] }\end{array}$ \\
\hline 39 & Liver & 2 years & Not reported & $\begin{array}{l}\text { Fever and poor } \\
\text { appetite }\end{array}$ & $\begin{array}{l}\text { Blood culture } \\
\text { and serology }\end{array}$ & Rifampin, TMP/SMX & 8 weeks & $\begin{array}{l}\text { Xie et al. } \\
\text { [16] }\end{array}$ \\
\hline 7 & Liver & 2 years & $\begin{array}{l}\text { Lives in endemic area \& raw } \\
\text { cheese consumption }\end{array}$ & Fever & Serology & Rifampin, TMP/SMX & 3 months & $\begin{array}{l}\text { Islek et al. } \\
\text { [11] }\end{array}$ \\
\hline 12 & Liver & 5 years & Lives in endemic area & $\begin{array}{l}\text { Fever and hip } \\
\text { pain }\end{array}$ & $\begin{array}{l}\text { Blood culture } \\
\text { and serology }\end{array}$ & Doxycycline, rifampin & 8 weeks & $\begin{array}{l}\text { Sutcu et al. } \\
\text { [12] }\end{array}$ \\
\hline 20 & Kidney & 4 months & Occupation & $\begin{array}{l}\text { Fever and } \\
\text { cough }\end{array}$ & Serology & Rifampin, doxycycline & 6 weeks & $\begin{array}{l}\text { Ay et al. } \\
{[17]}\end{array}$ \\
\hline 63 & Kidney & 8 years & Lives in endemic area & Fever & $\begin{array}{l}\text { Blood culture } \\
\text { and serology }\end{array}$ & $\begin{array}{l}\text { Ciprofloxacin, } \\
\text { doxycycline }\end{array}$ & $\begin{array}{l}2 \text { weeks } 6 \\
\text { weeks }\end{array}$ & $\begin{array}{l}\text { Inayat et al. } \\
\text { [10] }\end{array}$ \\
\hline 51 & Heart & 3 months & Farmer with animal contact & $\begin{array}{l}\text { Fever, chills, } \\
\text { and leukopenia }\end{array}$ & Serology & $\begin{array}{l}\text { Doxycycline, TMP- } \\
\text { SMX }\end{array}$ & 3 months & $\begin{array}{l}\text { Nair et al. } \\
{[14]}\end{array}$ \\
\hline
\end{tabular}

TABLE 3: Brucellosis cases in solid organ transplant recipients reported in the literature.

All cases presented with fever and the majority also had high inflammatory markers. Direct animal contact and/or raw dairy product consumption was reported in a few cases but being from highly endemic areas was the most common risk factor reported in the setting of organ transplantation.

Pulmonary involvement in brucellosis is rare. The largest reported case series came from Turkey in 2003 (37 cases) [18], 2005 (11 cases) [4], and 2014 (133 cases) [19]. Other reported case reports were post renal and liver transplantation [20]. Fever and cough were the two most common presenting symptoms. Extrapulmonary involvement was present in $27 \%-75 \%$ of the patients. The radiological manifestations varied, with lobar infiltrate/consolidations as the most common presenting radiological feature. Other presentations such as pulmonary nodules or pleural effusion have also been reported. The treatment regimen was not consistent across the reported cases of Brucella pneumonia. A systematic review of the treatment of Brucella pneumonia found that a combination of doxycycline and rifampin is the most commonly used regimen followed by doxycycline and aminoglycosides. All treatment regimens resulted in an excellent prognosis with mortality reported to be $<1 \%[19]$.

\section{Conclusions}

In conclusion, Brucella is a rare complication post solid organ transplant. The small number of reported cases could be due to underreporting. Brucella pneumonia is a well-known manifestation of Brucellosis. In highly endemic areas, Brucella pneumonia should be considered as a differential diagnosis of pneumonia, especially in post solid organ transplant patients. A combination of the commonly used doxycycline and rifampin or doxycycline and aminoglycosides showed an excellent prognosis with a very low mortality rate.

\section{Additional Information \\ Disclosures}

Human subjects: Consent was obtained by all participants in this study. King Faisal Specialist Hospital and Research Center issued approval approval 2200088. Disclosures Human subjects: Consent was obtained by 
all participants in this study. King Faisal Specialist Hospital and Research Center issued approval 2200088. Your application to submit manuscript/abstract/poster/oral presentation titled "First case of Brucella pneumonia in a lung transplant patient. Case report and review of the literature" was received by the Office of Research Affairs (ORA) on 04 March 2020. It has been assigned Publication No. 2200088 (No. appears in the upper left side of the publication submission form) and is cleared for publication (copy attached). Please use this number in your future correspondences with ORA regarding this publication. Conflict of interest: In compliance with the ICMJE uniform disclosure form, all authors declare the following: Payment/services info: All authors have declared that no financial support was received from any organization for the submitted work. Financial relationships: All authors have declared that they have no financial relationships at present or within the previous three years with any organizations that might have an interest in the submitted work. Other relationships: All authors have declared that there are no other relationships or activities that could appear to have influenced the submitted work. Conflicts of interest: In compliance with the ICMJE uniform disclosure form, all authors declare the following: Payment/services info: All authors have declared that no financial support was received from any organization for the submitted work. Financial relationships: All authors have declared that they have no financial relationships at present or within the previous three years with any organizations that might have an interest in the submitted work. Other relationships: All authors have declared that there are no other relationships or activities that could appear to have influenced the submitted work.

\section{References}

1. Corbel MJ, Food and Agriculture Organization of the United Nations, World Health Organization, World Organisation for Animal Health: Brucellosis in Humans and Animals. World Health Organization, Geneva; 2006.

2. Bakheet HG, Alnakhli HA: Brucellosis in Saudi Arabia: review of literature and epidemiology. J Trop Dis. 2019, 7:1-4. 10.4172/2329-891X.1000304

3. Franco MP, Mulder M, Gilman RH, Smits HL: Human brucellosis. Lancet Infect Dis. 2007, 7:775-786. 10.1016/S1473-3099(07)70286-4

4. Hatipoglu CA, Bilgin G, Tulek N, Kosar U: Pulmonary involvement in brucellosis. J Infect. 2005, 51:116-119. 10.1016/j.jinf.2004.10.004

5. Al-Anazi KA, Al-Jasser AM: Brucellosis in immunocompromised hosts. Arch Organ Transplant. 2016, 1:001021. 10.17352/2640-7973.000001

6. Tuon FF, Gondolfo RB, Cerchiari N: Human-to-human transmission of Brucella - a systematic review . Trop Med Int Health. 2017, 22:539-546. 10.1111/tmi.12856

7. Yousif B, Nelson J: Neurobrucellosis -- a rare complication of renal transplantation . Am J Nephrol. 2001, 21:66-68. 10.1159/000046223

8. Einollahi B, Hamedanizadeh AK, Alavian SM: Brucellosis arthritis -- a rare complication of renal transplantation: a case report. Transplant Proc. 2003, 35:2698. 10.1016/j.transproceed.2003.08.038

9. Ting IW, Ho MW, Sung YJ, Tien N, Chi CY, Ho HC, Huang CC: Brucellosis in a renal transplant recipient . Transpl Infect Dis. 2013, 15:191-195. 10.1111/tid.12125

10. Inayat F, Mahboob M, Ali NS, Bokhari SRA, Ashraf A: Brucellosis in renal transplant recipients: a comparative review of 5 cases. BMJ Case Rep. 2018, 2018:bcr-2018-225865. 10.1136/bcr-2018-225865

11. Islek A, Sayar E, Yilmaz A, Gunseren F, Artan R: Relapsing brucellosis after liver transplantation in a child: what is the appropriate regimen and duration of therapy?. Transplantation. 2013, 96:6-7. 10.1097/TP.0b013e318296fd1a

12. Sutcu M, Gokceer D, Akturk H, et al.: Brucella infection in a child with progressive familial intrahepatic cholestasis type 2 who had undergone liver transplantation. Pediatr Transplant. 2015, 19:146-148. 10.1111/petr.12555

13. Polat KY, Tosun MS, Ertekin V, Aydinli B, Emre S: Brucella infection with pancytopenia after pediatric liver transplantation. Transpl Infect Dis. 2012, 14:326-329. 10.1111/j.1399-3062.2011.00709.x

14. Nair VV, Appukuttan M, Narayan KV, Nair JTK: Brucellosis after cardiac transplantation. Ann Thorac Surg. 2019, 107:31-32. 10.1016/j.athoracsur.2018.05.054

15. Bishara J, Robenshtok E, Weinberger M, Yeshurun M, Sagie A, Pitlik S: Infective endocarditis in renal transplant recipients. Transpl Infect Dis. 1999, 1:138-143. 10.1034/j.1399-3062.1999.010208.x

16. Xie M, Rao W, Shen Z, Jia J: Brucellosis infection in an adult liver transplant recipient. Transpl Infect Dis. 2014, 16:516-518. 10.1111/tid.12204

17. Ay N, Kaya S, Anil M, Alp V, Beyazit U, Yuksel E, Danis R: Pulmonary involvement in brucellosis, a rare complication of renal transplant: case report and brief review. Exp Clin Transplant. 2018, 16:757-760. 10.6002/ect.2015.0324

18. Pappas G, Bosilkovski M, Akritidis N, Mastora M, Krteva L, Tsianos E: Brucellosis and the respiratory system. Clin Infect Dis. 2003, 37:95-99. 10.1086/378125

19. Erdem H, Inan A, Elaldi N, et al.: Respiratory system involvement in brucellosis: the results of the Kardelen study. Chest. 2014, 145:87-94. 10.1378/chest.13-0240

20. Solera J, Solis Garcia Del Pozo J: Treatment of pulmonary brucellosis: a systematic review . Expert Rev Anti Infect Ther. 2017, 15:33-42. 10.1080/14787210.2017.1254042 